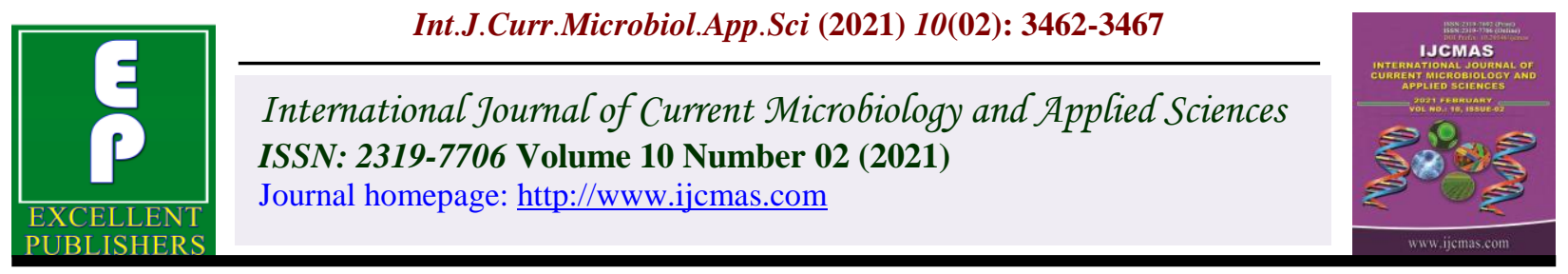

\title{
Effect of Abiotic Factors on Occurrence of Leaf Folder, Cnaphalocrocis medinalis Guenee in Basmati Rice in Western Plain Zone of Uttar Pradesh
}

\author{
Rajat Deshwal $^{1 *}$, S. K. Sachan ${ }^{1}$, Visvash Vaibhav ${ }^{1}$, Nitin Kumar ${ }^{1}$ and Ankit Kumar ${ }^{2}$ \\ ${ }^{1}$ Department of Entomology, ${ }^{2}$ Department of Plant Pathology, Sardar Vallabhbhai Patel \\ University of Agriculture and Technology, Meerut, (U.P.), India \\ *Corresponding author
}

\section{A B S T R A C T}

\section{Keywords \\ Basmati rice, Cnaphalocrocis medinalis, Leaf damage, Correlation}

Article Info

Accepted:

24 January 2021 Available Online: 10 February 2021
The present investigation was conducted to study the effect of abiotic factors on occurrence of leaf folder, Cnaphalocrocis medinalis Guenee in basmati rice in western plain zone of Uttar Pradesh during Kharif 2017 and 2018. Observations of $C$. medinalis infestation were recorded at weekly interval, 15 days after transplanting till harvesting. The peak period of pooled maximum leaf damage $(13.40 \%)$ of both cropping seasons was recorded in $39^{\text {th }}$ standard week. Thereafter, infestation declined gradually. The correlation matrix between infestation of leaf folder with weather parameters indicated that there was a positive correlation with maximum temperature $(\mathrm{r}=0.38)$, minimum temperature $(\mathrm{r}=0.50)$, morning relative humidity $(\mathrm{r}=0.01)$, evening relative humidity $(\mathrm{r}=0.70)$ and rainfall $(\mathrm{r}=0.13)$ with the leaf damage caused by leaf folder.

\section{Introduction}

Rice an important staple food crop of India support more than two-third of its population (7). In the World, rice is grown about in 167.24 million ha with an annual production of 769.65 million tonnes and $46.02 \mathrm{q} / \mathrm{ha}$ of productivity. In India, rice crop occupies an area of about 43.78 million ha with a total production of 168.50 million tones and the productivity of $38.50 \mathrm{q} / \mathrm{ha}^{(2)}$. Insect pests are responsible for considerable yield reduction of various crops in tropical Asian countries ${ }^{(9)}$. About 128 species of insects have been reported to ravage the rice field. Out of this only 15 to 20 insects are regarded as economically obnoxious species ${ }^{(4)}$. Rice leaf folder, Cnaphalocrocis medinalis (Guenee) was considered to be a minor pest earlier but after 1980's it has become a major pest and reported to have more than one species of leaf folder in rice ecosystem. Excessive application of nitrogenous fertilizers and misuse of insecticides are the factors for this minor pest gaining major pest status ${ }^{(1)}$. The leaf folder larva fastens edges of leaves together, fold them longitudinally and feed on green matter from inside the folded leaf. Damaged leaf produces white streaks, become membranous and ultimately reduces 
photosynthetic activity of the plant ${ }^{(8)}$. Each insect pest requires certain set of weather conditions for their survival and multiplication.

Therefore, it is necessary to gain a thorough knowledge on relation of weather parameters to insects (Entomo-climatology) which will be very useful to farmers in all areas where major insect pests are appearing year after year and causing serious damage to crops.

Keeping in view, the severity of damage by leaf folder in rice growing area of western Uttar Pradesh and the influence of weather factors on their growth, multiplication and distribution. For developing any pest management programme, specific agroecosystem information on abundance and distribution of pest in relation to weather parameters is a basic requirement.

\section{Materials and Methods}

The field experiments were carried out during June to October 2017 and 2018 at Crop Research Centre, Sardar Vallabhbhai Patel University of Agriculture and Technology, Meerut Uttar Pradesh. The experiment was conducted in Randomized Block Design (RBD) with rice cv. Pusa basmati 1. The spacing adopted was $20 \times 20 \mathrm{~cm}$ and all the cultural operations except plant protection were followed as per the recommendations. The observations of $C$. medinalis infestation were recorded at weekly interval, 15 days after transplanting till harvesting. Observation on leaf folder infestation, number of damaged leaf were counted per five hills. To the study instantaneous effect of major abiotic factors viz., maximum temperature, minimum temperature, average temperature, morning relative humidity, evening relative humidity, average relative humidity, rainfall on the population of $C$. medinalis, correlation coefficient was worked out. Finally data so obtained were worked out and converted into percentage of leaf damage (Per cent leaf damage $=$ Total number of leaf damage $\mathrm{X}$ 100) / Total number of leaf ). The weekly meteorological data recorded at ICAR-Indian Institute of Farming System Research, Modipuram (Meerut) during the kharif 2017and 2018 from July to October period were utilized for this purpose.

\section{Statistical analysis}

The influence of weather parameters on damage done by $C$. medinalis (leaf damage) was analyzed by correlation analysis for a period of two years. The data was analyzed by using statistical software SPSS 16.0.

\section{Results and Discussion}

The impact of major abiotic factors on the incidence of per cent leaf damage at weekly interval during Kharif 2017 and 2018 according to standard weeks.

\section{During Kharif season 2017}

The data are depicted in Fig 1 revealed that the infestation of C.medinalis appeared first on $32^{\text {th }}$ standard week and continued till the $44^{\text {th }}$ standard week. The infestation of leaf folder recorded as leaf damage ranged from 2.48 to 14.23 percent during Kharif, 2017. The infestation increased from $39^{\text {th }}$ standard week (last week of September). During this period the weather parameters like temperature, relative humidity and rainfall ranged from 21.00 to $33.40{ }^{0} \mathrm{C}, 58.90$ to 98.70 percent and $0.00 \mathrm{~mm}$, respectively. Thereafter infestation declined.

The correlation between infestation of leaf folder with weather parameters are given in Table 1. The leaf folder infestation showed positive correlation with maximum temperature $(r=53)$, minimum temperature 
$(\mathrm{r}=0.52)$, morning relative humidity $(\mathrm{r}=$ $0.12)$, evening relative humidity $(\mathrm{r}=0.28)$ and rainfall $(\mathrm{r}=0.11)$.

\section{During Kharif season 2018}

The data depicted in Fig. 2 revealed that the infestation of leaf folder appeared first on $32^{\text {th }}$ standard week and continued till the $44^{\text {th }}$ standard week. The infestation of leaf folder recorded as leaf damage ranged from 1.05 to 12.5 percent during Kharif, 2018. The infestation increased from $33^{\text {th }}$ standard week and reached at maximum during $39^{\text {th }}$ standard week (last week of September). During this period the weather parameters like temperature, relative humidity and rainfall ranged from 23.00 to $32.60{ }^{0} \mathrm{C}, 75.70$ to 94.00 percent and $37.00 \mathrm{~mm}$, respectively. Thereafter the infestation declined.

The leaf folder infestation showed positive correlation with maximum temperature $(\mathrm{r}=$ 0.13), minimum temperature $(\mathrm{r}=0.47)$, evening relative humidity $(\mathrm{r}=0.70)$ and rainfall $(\mathrm{r}=0.13)$ and negative correlation with morning relative humidity (Table 1 ).

Table.1 Correlation between seasonal incidence of Cnaphalocrocis medinalis in relation to abiotic factors

\begin{tabular}{|c|c|c|c|}
\hline \multirow{2}{*}{ Weather Parameters } & \multicolumn{3}{|c|}{ Correlation coefficient (r) } \\
\cline { 2 - 4 } & \multicolumn{3}{|c|}{ Percent leaf damage } \\
\cline { 2 - 4 } & $\mathbf{2 0 1 7}$ & $\mathbf{2 0 1 8}$ & Pooled \\
\hline Maximum Temp. ( $\left.{ }^{\mathbf{0}} \mathbf{C}\right)$ & 0.532 & 0.132 & 0.387 \\
\hline Minimum Temp. ( $\mathbf{0} \mathbf{C})$ & 0.528 & 0.470 & 0.505 \\
\hline Average & 0.602 & 0.390 & 0.500 \\
\hline Morning RH (\%) & 0.123 & -0.121 & 0.012 \\
\hline Evening RH (\%) & 0.283 & 0.701 & 0.700 \\
\hline Average & 0.386 & 0.562 & 0.690 \\
\hline Rainfall (mm) & 0.119 & 0.136 & 0.132 \\
\hline
\end{tabular}

Fig.1 Seasonal incidence of rice leaf folder, $C$. medinalis in relation to abiotic factors during Kharif, 2017

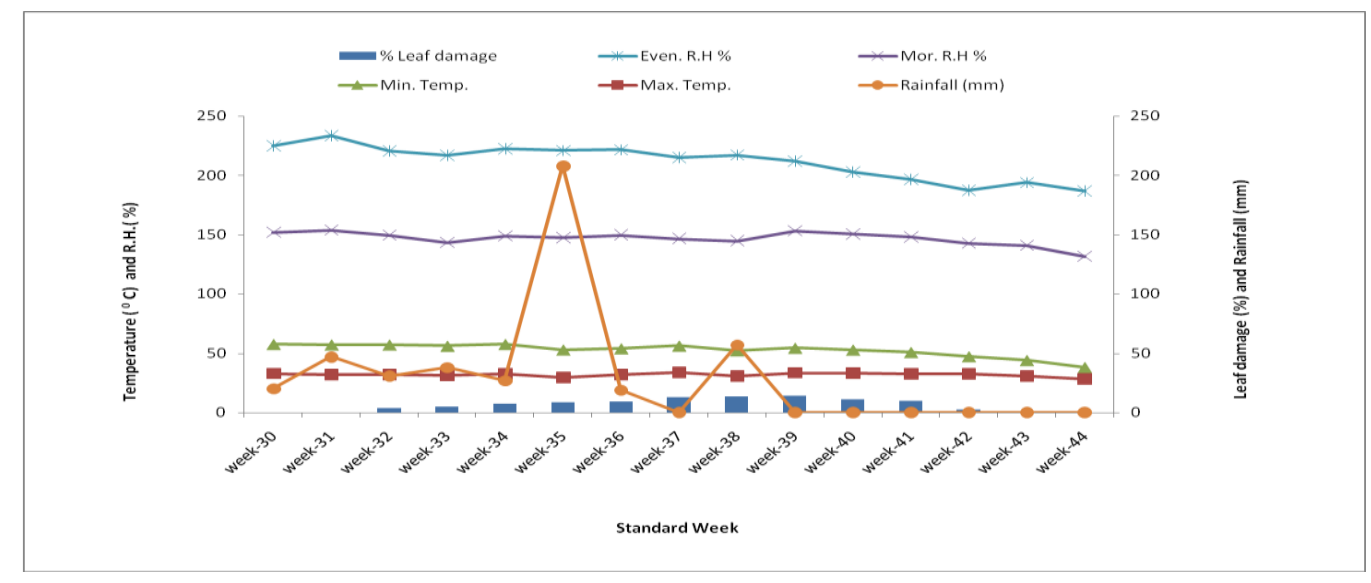


Fig.2 Seasonal incidence of rice leaf folder, $C$. medinalis in relation to abiotic factors during Kharif, 2018

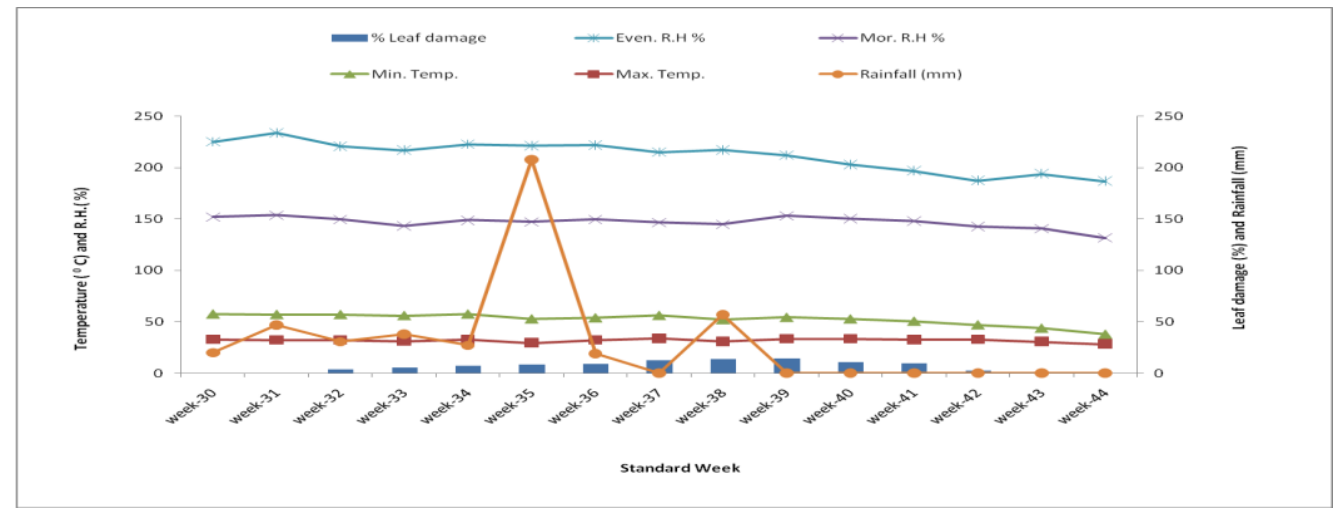

Fig.3 Pooled data for incidence of rice leaf folder, $C$. medinalis in relation to abiotic factors (Kharif, 2017 and 2018)

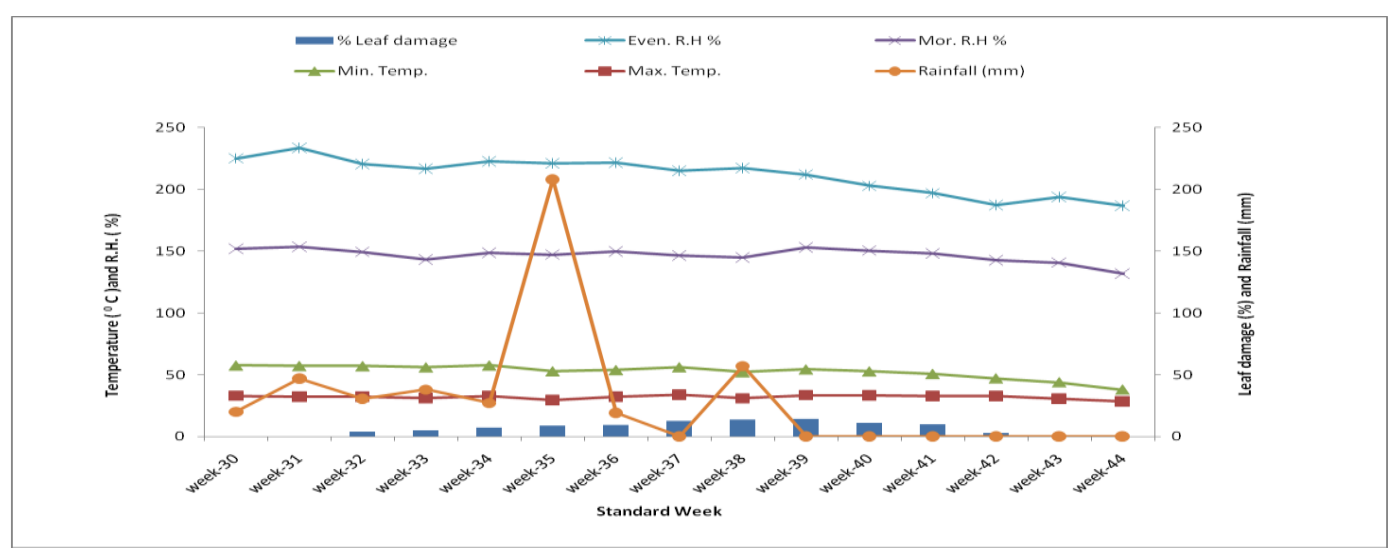

Pooled data during Kharif season 2017 and 2018

Perusal of pooled data showed that the $C$. medinalis infestation with 3.20 percent leaf damage was appeared from $32^{\text {nd }} \mathrm{SW}$ and recorded its peak with 13.40 percent leaf damage during $39^{\text {th }}$ SW. (last week of September). During this period the weather parameters like temperature, relative humidity and rainfall ranged from 22.00 to $33.00{ }^{\circ} \mathrm{C}$, 67.30 to 96.40 percent and $18.50 \mathrm{~mm}$, respectively. Thereafter, infestation declined gradually. Further, this infestation turn down and observed up to the harvest with minimum infestation of $1.80 \%$ leaf damage at $42^{\text {nd }} \mathrm{SW}$ (Figure 3).
The correlation matrix between infestation of leaf folder with weather parameters indicated that there was a positive correlation with minimum temperature $(\mathrm{r}=0.50)$, maximum temperature $(\mathrm{r}=0.38)$, morning relative humidity $(\mathrm{r}=0.01)$, evening relative humidity $(\mathrm{r}=0.70)$ and rainfall $(\mathrm{r}=0.13)$ with the leaf damage caused $C$. medinalis (Table 1). The observations recorded present investigation are similar to the finding of earlier workers like ${ }^{(5)}$ who reported the maximum infestation of leaf folder during second fortnight of September. ${ }^{(6)}$ reported maximum infestation of $C$. medinalis during $41^{\text {st }}$ standard week. (3) reported that the leaf folder population was found maximum in the last week of August and first week of September (14.50-16.75 
damaged leaves/10 hills). The leaf folder showed positive correlation with maximum temperature $(\mathrm{r}=0.26)$ and $(\mathrm{r}=0.23)$ whereas, minimum temperature $(\mathrm{r}=0.74)$ and $(\mathrm{r}=$ $0.075)$, morning relative humidity $(\mathrm{r}=0.72)$ and $(\mathrm{r}=0.79)$, evening relative humidity $(\mathrm{r}=$ $0.65)$ and $(\mathrm{r}=0.74)$, rainfall $(\mathrm{r}=0.65)$ and $(\mathrm{r}=$ 0.68), respectively during 2017 and 2018, reported. Similar observation were made by (10) who observed that the larval population of leaf folder increased gradually till $38^{\text {th }}$ week with 10 larvae/ 10 hills. The correlation analysis revealed a positive correlation with evening ( $\mathrm{r}=0.580)$ and average relative humidity $(\mathrm{r}=0.565)$. However a positive correlation was obtained with temperature $(\mathrm{r}$ $=0.366)$, rainfall $(\mathrm{r}=0.236)$ and morning relative humidity $(\mathrm{r}=0.182)$.

In conclusion the peak period of $C$. medinalis was recorded in last week of September $\left(39^{\text {th }}\right.$ standard week) during Kharif, 2017 and 2018. The seasonal incidence of $C$. medinalis delineated the leaf folder population build up and interaction with weather parameters, which can be utilized for decision making. The correlation analysis between infestation of leaf folder with environmental factors indicated that there was a positive correlation with maximum temperature, minimum temperature, morning relative humidity, evening relative humidity and rainfall with the leaf damage caused by leaf folder.

\section{Acknowledgements}

Authors are highly thankful to Head, Department of Entomology, and the Director Research, Sardar Vallabhbhai Patel University of Agriculture and Technology, Meerut, for the necessary facilities and encouragement during course of present investigation and also thankful to ICARIndian Institute of Farming System Research, Modipuram (Meerut) for providing weather data.

\section{References}

1. Dhaliwal GS, Shahi H N, Gill PS, Maskina MS. 1979. Field reaction of rice varieties to leaf folder at various nitrogen levels. International. Rice Research Newsletter. 1979; pp. 4-7.

2. Food and agriculture organization. http://faostat.fao.org, 2017.

3. Kalita H, Avasthe RK, Ramesh K Effect of weather parameters on population buildup of different insect pests of rice and their natural enemies. Indian Journal of Hill Farming. 2015; 28(1): 69-72.

4. Kalode MB. Insect pest of rice and their management in Indian Perspectiveeds. S.D. Sharma and B.C. Nayak. Today and tomorrow printers and publishers (India). 2005; pp 819-854.

5. Ram M, Sachan SK, Singh G. Study on population build up of rice leaf folder, Cnaphalocrocis medinalis (Guenee) in relation to weather factors. International Journal of Advanced Research. 2014; 10(2): 75-77.

6. Nigam VD. Effect of abiotic factors on the population fluctuation of rice leaf folder, Cnaphalocrocis medinalis (Guenee) in Eastern Uttar Pradesh. Agricultural and Biological Research. 2009; 25 (2): 128-134.

7. Prakash A, Rao J, Singh ON, Tyagi, JP, Singh S, Rath PC. Rice the queen of central, AZARA Publication CRRI. 2007; pp. 1-40.

8. Sarao PS, Kaur H. Efficacy of ferterra $0.4 \%$ GR (chlorantraniliprole) against stem borers and leaf folder insect- pests of basmati rice. Journal of Environmental Biology. 2013; 35 (5): 815-819.

9. Savary S, Willocquet L, Elazegui FA, Castilla NP, Teng PS. Rice pest constraints in tropical Asia: quantification of yield losses due to rice 
pests in a range of production situations. Plant Disease. 2000; 84(3): 357-369.

10. Sulagitti A, Raghuraman M, Reddy MSS, Sathua SK. Seasonal variation in major insect pests incidence on rice and impact of various abiotic factors on their incidence under Varanasi conditions. Journal of Entomology and Zoology Studies. 2017; 5(3): 10601063.

\section{How to cite this article:}

Rajat Deshwal, S. K. Sachan, Visvash Vaibhav, Nitin Kumar and Ankit Kumar. 2021. Effect of Abiotic Factors on Occurrence of Leaf Folder, Cnaphalocrocis medinalis Guenee in Basmati Rice in Western Plain Zone of Uttar Pradesh. Int.J.Curr.Microbiol.App.Sci. 10(02): 3462-3467. doi: https://doi.org/10.20546/ijcmas.2021.1002.382 